\title{
Youth of India in the Novels of Chetan Bhagat
}

\author{
Renuka Mishra \\ Binod Bihari Mahto Koylanchal University, Jharkhand, India \\ Corresponding author: renukamishra1250@gmail.com
}

Received: 08-01-2020

Revised: $12-04-2020$

Accepted: 26-05-2020

\begin{abstract}
It is the younger generation who takes country's progress forward but young generation has to go through a lot transformation at this age. They are worried and scared about their future career, getting good percentage so that they could get admissions in top colleges. They also go through hard time handling personal and emotional affairs. This is the delicate age where they also feel like falling in love. So, there are thousands of things going on in their minds. There is a high percentage of unemployment in India. Younger generation is more worried, concerned and disturbed about their uncertain future. Chetan Bhagat is a contemporary young and famous writer who brings forth the issues of youth in his novels, newspaper articles. He also works as a motivational speaker and guide younger generation on their career choices. His most of the novels have made record sales and are known as best sellers. Though he is an English Language writer but still his style of writing is so simple that those who have a tight hand at understanding English can understand the storyline without taking the help of heavy weighted English dictionaries. From the very beginning of his career as a novelist he explored the issues and problems of youth through his well-etched characters.
\end{abstract}

Keywords: Delicate Age, Uncertain Future, Problems of Youth and Well-Etched Characters

He throws some light on the issues in our education system, which is based only on getting high percentage in class by learning theories and books word by word in his novel, Five Point Someone. In another novel, Revolution 2020, he raises and exposes the issue of corruption and politics in colleges and universities. The protagonist in the novel, Gopal, comes from a poor family. The story reveals the harsh reality of poverty who aspires and dreams big. The novel exposes the dirty politics prevailed in professional colleges. It also explores the hurdles coming in the way of career making choices along with private institutions and coaching classes exploiting aspiring students. These private institutions are making big money showing them fake dreams.

In another novel, Three Mistakes of My Life, Chetan sheds light on the different dimensions of Indian youth.
He explores the dreams, aspiration, and greed in today's generation. He also exposes the politics being played around the society on the basis of caste and religion. This religious and classes difference starts from their homes. Children of the comparatively rich class are not allowed to play or spend time with poorer class. Children of one religion is taught about the negatives of other religion and fanatics inculcate extremism in the crop of newer generation. This religious difference is increasing day by day and there is always a fear of breaking out religious riots on small fights and petty issues.

History reveals that religiously at different times of our country played a very negative role and now let us trust the responsibility of maintaining communal harmony to youths of our country. Ours is a land of various religions and culture and three differences of them cave a hatred 
and bitterness among the followers of different religions. Youth can bring a positive change in controlling unrest caved by the religious bitterness of different religions. Youth may awaken the nation so that every person becomes a true nation of our country. Our country should identify the causes of unrest among youth and take enormous efforts to dispel this. (Tiwari, 4)

Younger generation also has the love for the game cricket. In India, cricket has become a parallel religion and extraordinary players become their role model. The game of cricket has taken the front seat leaving other sports behind. From the very early age, children take bat and ball and start play cricket in their homes, wherever they find space like corridors, garage, or on the terrace. People are crazy about this sport and comment on each and every ball being played or thrown in the ground.

Chetan Bhagat has also explored the biggest problem of all times in Indian society is corruption. The problem of corruption is so engraved that it has engulfed every corner and profession of India. Chetan has also felt the gravity of corruption and he made this social issue the background of his novel Revolution 2020. Chetan has exposed the corruption prevailed in education system also. The story of Revolution 2020 is woven in such a way that the characters are shown to be the victim of this social evil. The situation got so much worse that the protagonist of the novel ultimately chooses the path of corruption to be become a successful businessman.

If on one hand, Chetan exposes the serious issue of corruption in India and its adverse consequences on today's youth, on the other hand he further explores the feeling of love in the young hearts. This time, the novel explores the love triangle story. Two friends fall in love with the same girl. One person is very ambitious and by hook or crook wants to earn money and comforts of life. The other person wants to use his intelligence to bring revolution in the country.

A research scholar, Radha DR explores the corrupt and immoral way profit making engineering colleges. She states that giving bribes and taking bribes in the schools and colleges are very common. One has to bribe in the name of donation to the colleges to book a seat in an engineering college. Revolution 2020 portrays the state of matters of Indian education system, loaded with corruption and not helpful in any way to the commonalities. A critic of the books properly identifies the chief purpose of the book which is to "uncover... the corrupt education system, the profit making private engineering colleges, issue of corrupting etc." thus giving "the book a present-day touch." Further, the reviewer says, "Probably it wasn't destined since he started writing the book 2 years back, but the issue of corruption has been reignited by Anna Hazare. And for the same reason a lot of readers would associate with the issues mentioned in the book pretty well." (Transition) Another analysis of the book identifies "how corruption is prevalent in the education system, how bribes are taken and given at every nook-n-corner, how anyone and everyone are eligible to open educational institutions -if you have adequate land. The book also touches upon the plight of students in India and how important it is to get into one of the "top" colleges."

One more novel, Half Girlfriend, also explores problems of Indian youth. In the novel, Chetan's character is a countryside innocent boy. Everybody knows the difference in the village or small town boy and a boy living in metropolitan city, a city which is advanced and modernized. This novel also sheds some light on the lives of those students who migrate to big cities for higher education. Coming from the small town, these students are under confident as compared to the metropolitan young generation who is smarter in many ways. One can notice the difference of confidence in their body language and way of talking. Madhav, the main character of the novel comes to Delhi from a village in Bihar. He tries hard to match with the smartness of the boys in the major cities. His spoken English is not good so he feels out of place in a party. He falls in love with a rich high society girl whose lifestyle is modern and westernized. She is more confident, poised and graceful. The novel studies the innocence and simplicity of small town versus the modernized behavior of metropolitan youth.

Where most of Chetan Bhagat's novel explores the lives of youth, confusion about their career options and the struggle, he explored love and passion of youth in their hearts through his novel, Two States. This novel 
explores the personal, familial and emotional aspects of youth. Two people from different religion and caste fall in love. This novel explores the cultural and societal difference between the two religions. Two States is about the struggle in the lives of two people who love each other and wants to marry but because they belong to two different religions there are a lot of issues and problems among their families. Boy is from the Punjabi family and Girl belongs to Tamil family. Chetan explores this difference in a comical and hilarious way. For a Tamilian, higher education and getting a number of degrees is priority but for a Punjabi family their priority is more towards materialistic things like, owning a big house and a luxury car. Chetan explored this societal and mindset difference in a lighter mode. Chetan himself belongs to a Punjabi family so he could understood the aspirations of a Punjabi guy.

\section{CONCLUSION}

Youth is the future builder of a country. They need to have their goals and aspirations clear in their minds. No one can deny the fact that there are a lot of expectations from the youth but they are burdened with these expectations. Chetan through his novels tries $t$ explore the mindset of youth, their struggle and fear for making a good career choices. Sometimes they get carried away by the societal pressure and the other times politicians use their energy and strength for wrongful and selfish use. This new generation meet people from different sections of society in their colleges and universities. Chetan Bhagat has explored various different angles of younger generation. He very well explored the angle of love in almost all his novels. The other common thing in his novel is college going youth and the hindrances coming their way at this age. Revolution 2020 explores the corruption prevailed in the education system. It also has explored the aspiration, greed, and money-mindedness in today's youth. One Night @ the Call Center explores the personal problems faced by the young people and difficulties coming in the professional front. How the private organizations and multinational companies are exploiting its employees. If these novels explores the problems of youth then Two States also studies the import role of a family in the lives of youth. Despite their career uncertainty and cut-throat competition, they also care about their family. The characters coming from two different states and different cultural setup, they try to convince their families to get married. They do not want to run away from their respective homes to get married. They their families to agree to their likes and choices and live together. They understand the cultural difference from each other. They can play a big role in making the revolutionary changes in the fundamental norms and give a positive thought and direction to the society. They must use their energy and power in making the future nation building and barring themselves from being a puppet of the anti-social elements.

\section{REFERENCES}

“Revolution 2020". En.Wikipedia.Org, 2020, https://en.wikipedia. org/wiki/Revolution_2020. Accessed 11 May 2019.

“Half Girlfriend”. En.Wikipedia.Org, 2020, https://en.wikipedia. org/wiki/Half_Girlfriend. Accessed 14 Aug 2019.

Tiwari, Sapna. Religious and Cultural Differences and Youth of India in The Novels of Chetan Bhagat. IJELLH (International Journal of English Language, Literature in Humanities), [S.1.], v. 1, n. 1, p. 5, june 2013. ISSN 2321-7065. Available at: <https:// ijellh.com/OJS/index.php/OJS/article/view/2>. Date accessed: 20 Jan. 2019. doi: https://doi.org/10.24113/ijellh.v1i1.2.

Radha, Dr.; C, Dr. Premalatha.. Post- Modern elements in the novels of Chetan Bhagat. IJELLH (International Journal of English Language, Literature in Humanities), [S.1.], v. 6, n. 8, p. 11, aug. 2018. ISSN 2582-3574. Available at: <https://ijellh. com/OJS/index.php/OJS/article/view/4570>. Date accessed: 16 March. 2019. doi: https://doi.org/10.24113/ijellh.v6i8.4570. 
